\title{
CUSTOMER SATISFACTION AS A RESULT OF COMBINATION OF FOOD DISPLAY \& QUALITY
}

\author{
Aditya N. Putra \\ Department of Hotel \& Tourism Management, Faculty of Business \& Social Sciences, \\ International University of Liaison Indonesia (IULI) \\ aditya.nova01@gmail.com \\ Samuel PD Anantadjaya \\ Department of International Business Administration, Faculty of Business \& Social Sciences, \\ International University of Liaison Indonesia (IULI) \\ ethan.eryn@gmail.com \\ Irma M. Nawangwulan \\ Department of Hotel \& Tourism Management, Faculty of Business \& Social Sciences, \\ International University of Liaison Indonesia (IULI) \\ mnwulan@gmail.com
}

Received: January, 2020; Accepted: May, 2020; Published: September, 2020

DOI: https://doi.org/10.24123/jmb.v19i2

\begin{abstract}
Nowadays, visualization of food appearance has become an important factor in influencing customer satisfaction which is creating an unforgettable experience when people visit to the restaurant. The aspect of visualizing the appearance of food must also be balanced by good food quality in the restaurant. The purpose of this study was to identify the effect of visualization of food appearance and food quality in achieving customer satisfaction in Tutup Panci Bistro. In this study, visualization of food appearance has five important factors that support in achieving customer satisfaction, which are; component of the material used, color selection, food texture, shape and size, and layout. Therefore, in previous study, quality of food has three important factors, which are: the taste of food, the variety of menus, and the nutritional content of food. The methodology used in this study was quantitative and qualitative, whereas, quantitative data collection was obtained through questionnaires to guests at Tutup Panci Bistro. Meanwhile, qualitative data is obtained through interviews with food influencers/reviewers. Based on the results obtained, appearance and quality of food have a significant positive influence towards customer satisfaction at Tutup Panci Bistro. Keywords: food display, food quality, customer satisfaction
\end{abstract}

\begin{abstract}
Abstrak
Visualisasi tampilan makanan yang baik telah menjadi faktor yang penting dalam mempengaruhi kepuasan seseorang dalam menciptakan sebuah pengalaman yang tidak terlupakan ketika mereka berkunjung ke restoran. Aspek visualisasi tampilan makanan juga harus dapat diimbangi oleh kualitas makanan yang baik. Tujuan pada penelitian ini adalah mengidentifikasi pengaruh visualisasi tampilan dan kualitas makanan terhadap kepuasan pelanggan di Tutup Panci Bistro. Di dalam penelitian ini, visualisasi tampilan makanan mempunyai lima faktor penting yang mendukung dalam mencapai kepuasan pelanggan, yaitu; komponen bahan yang digunakan, pemilihan warna, tekstur makanan, bentuk dan ukuran, dan
\end{abstract}


tata letak. Sedangkan, kualitas makanan mempunyai tiga faktor penting, yaitu: rasa makanan, variasi menu, dan kandungan nutrisi makanan. Metodologi yang digunakan dalam penelitian ini adalah kuantitatif dan kualitatif, yang dimana, pengambilan data kuantitatif didapatkan melalui penyebaran kuisioner kepada 100 tamu di Tutup Panci Bistro. Data kualitatif diperoleh melalui wawancara dengan food influencer/reviewer. Berdasarkan hasil yang didapatkan, visualisasi dan tampilan makananan memliki pengaruh yang positif signifikan terhadap kepuasan pelanggan di Tutup Panci Bistro.

Kata Kunci: visualisasi tampilan makanan, kualitas makanan, kepuasan pelanggan

\section{INTRODUCTION}

In a restaurant business, restaurant owners need to ensure a unique concept to be able to always attract potential visitors. The involvement of social media to disseminate information about the restaurant has also become a basic need aside from only discounts, music entertainment, and the atmosphere of the restaurant (Bennet 2017). Food visualization can also be an attraction for restaurants and is used as the main basis in giving a positive impression to prospective visitors. Gitman \& McDaniel (2007), have stated that customer satisfaction is a person's feeling towards the pleasure and disappointment of the comparison of results expected by guests to a product received. This aspect of customer satisfaction can be seen as a key differentiator indicator and key as an element of business strategy for a restaurant.

Based on 2 research teams Soenawan \& Malonda (2015), and Faizah, Suryoko \& Saryadi (2013), product quality (Anantadjaya et al. 2015), quality of services offered (Exhibition et al. 2010, Ghimire 2012, Ha \& Jang 2010), and the atmosphere of the business location (Ghimire 2012, Githiri 2017, Fu'ad 2015), the price of the products and services provided (Bojanic 2007) are as several factors can affect customer satisfaction. The main product of the restaurant is certainly the food served. Measuring the quality of the food dish can be seen from the taste, appearance, portions and of course the price. From these factors, taste and appearance are a combination that is considered by restaurants (Faizah, Suryoko, \& Saryadi 2013).

Seeing the development that has existed until now, visualization of food offerings becomes an interest in itself. Restaurant visitors often take pictures of the food visualization display and upload the photo to their respective social media accounts. Referring to this, a distinct impression arises that the restaurant visitors seem to be relatively disregard the price and taste of the food offerings to get a new experience from the dishes (Velasco et al. 2016). If the food visualization display factor can be supported by delicious taste indicators and appropriate prices, customer satisfaction with a restaurant can occur. This customer satisfaction is specifically related to the reality of the dining experience in a restaurant, or what is called Customer Dining Satisfaction ", or " customer dining experience " (Putra 2019).

The chairman Indonesian Gastronomy Association (IGA), Indra Ketaren, stated that the owner of the restaurant tended to ignore the visualization of food dishes (Dhetira 2016), and the relative taste. For years, restaurant owners try to compete to ensure that the taste of their food must be very good. The discussions often lead to other crowded restaurants rather than studying the "customer experience" that other restaurants provide to evaluate the reasons why people visit the restaurant. It seems that restaurant owners forgot that the visitors decided to visit a restaurant not only to buy their food, but rather the desire to buy the value from the restaurant. In this case, the value (value) is a series of positive experiences that become the second thing in the minds of customers. One of these values display of food visualization has become a 
trend nowadays, which is also a sensational experience of customers (Dhetira, 2016). With reference to the phenomenon mentioned above, that is connected to the combination of restaurant visitors, food visualization, food quality and customer satisfaction, which is also strengthened by the statement from the chairman of the Indonesian Gastronomy Association regarding food visualization, the topic still needs research to be able to study the relationship between variables. The result of this study is expected to be a reference for restaurant businesses to start considering the role of the visualization/ appearance of their respective foods.

The food service industry is an old business around the world. The basic function of the food and beverage service industry is definitely to provide service to the food and beverage orders of the visitors/customers. The industry has penetrated all levels of society; hotels, restaurants, canteens, which are scattered in office factories, hospitals, schools / campuses, airplanes, trains (Goeldner \& Ritchie, 2009). History shows that France is the country that employs professional services for food and beverages in restaurants by the chef and delivered by waiter directly to the guest. Food and beverage menu can be differed to two choices, namely: a la carte and table d'hote, or a combination of selected menu options (Goeldner \& Ritchie 2009).

In the following illustration, it is clearly seen about the branches of the food and beverage industry in the world (Goeldner \& Ritchie 2009, Weaver \& Lawton 2014):

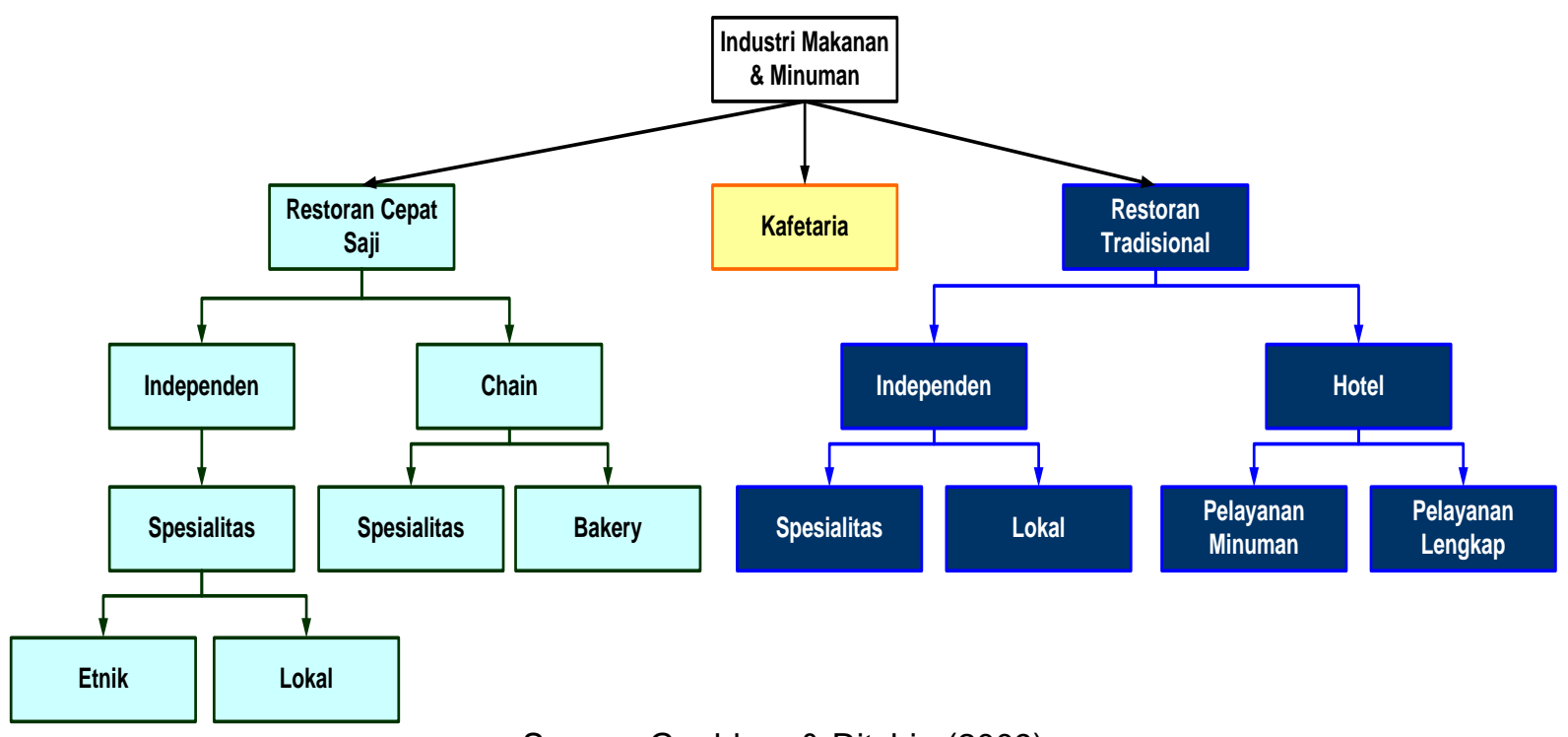

Source: Goeldner \& Ritchie (2009)

Figure 1. Food Service Industry

Display of food, or food visualization is an art by doing modifications, different processing, organizing, and decorating the food to enhance the aesthetic appeal of the food value. Experts from this food display is known as a food stylist who is demanded to always have creativity, good ideas and tastes, so that food dishes become interesting from various elements, such as; the arrangement, composition, color and appearance, thus it becomes very tempting for customers to immediately eat the dish. Design and formulation of " positive customer experience " needs to be recognized to be an initial step (Nawangwulan et al. 2012). The formulation of "positive customer experience" need to include all of the senses (Dhetira 2016).

Food Presentation or food display, or also referred to as the visualization is the art of processing, arranging and decorating food dishes on a plate to be able to increase the attractiveness. Customers' interest in a meal starts from their eyes first before finally eating the dish (Spence et al. 2016). The food served should look attractive by paying 
attention to the balance of color composition, texture, shape and arrangement of all elements on a plate (Labensky et al. 2014). Labensky et al. 2014) state that the arrangement of elements on a plate for a visualization of food is called platting. Some styles refer to as classic arrangement centered on the main food placed in front and "accompanied" with condiments and vegetables in the section behind. The preparation and presentation of the element must correspond to the clockwise direction; protein (at 6 o'clock position), vegetables (at 2 o'clock position), and starch (at 11 o'clock position) (Unilever Food Solutions 2016).

Aside from the classic arrangement, the Yong et al. (2013) stated that the appearance of a food can be said to have a good quality if physically from the food is served with an attractive packaging/display or added with information labels about the product. The display of a food is a series of interesting visualization processes offered by restaurants (Yong et al. 2013, Nisbets PLC 2019, The Manila Times 2014). A good composition in the appearance of food served needs to fulfill a balance (Collinge 2017, Motes, Malach, \& Kozhevnikov 2008, Spence et al. 2016, Ray 2015), which includes; selection of the right material components (Unilever Food Solutions 2016), different colors (Adam \& Ali 2014, Elliot \& Maier 2014, Hauff 2019, Mwangi 2010, Putra, Saroso, \& Anantadjaya 2015, Singh \& Srivastava 2011), interesting texture (Civille 2010; Haugaard 2015, Jeltema, Beckley, \& Vahalik 2015), the right shape (Spence et al.2016, Stewart \& Goss 2013), and beautiful layout (Chef Resources Inc. 2015, Unilever Food Solutions 2016). This composition can be added by decorating a display of such food with sauces, powdered sugar and/ or other decorations, without affecting the taste of the food substantially (Caribbean Hotel Association 2003, Nisbets PLC 2019, The Manila Times 2014).

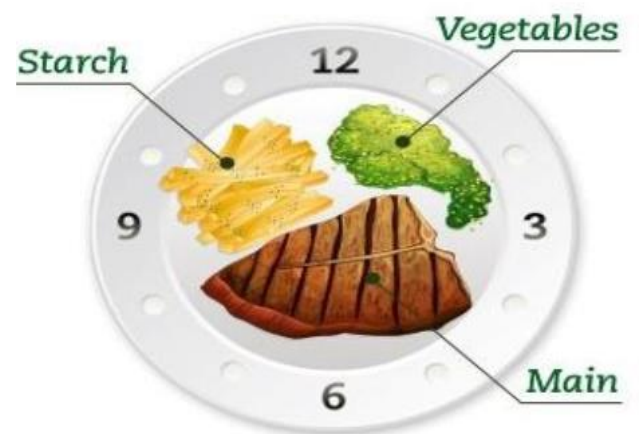

Source: Unilever Food Solutions (2016)

Figure 2. Food Display Focus Points

The selection of materials to be used is an important key in a food display. The food served should look simple [1] but attractive. The arrangement of a food on a plate should pay attention to aspects of balance [2], unity, and focus point. These factors can help to increase customer appetite. The layout of the material component used is symmetrical, the consumer visual sensor will relatively "lock in" the customer's attention to the center of the plate (Unilever Food Solutions 2016).

The display of food served on a plate should be able to have a balanced color variation. Color always has an important factor in a food, especially in its appearance. The main color should be soft, natural and compatible. Color can be classified together with the effect that has on the perception of people who feel it, such as colors that are considered warm include red, orange and yellow which can increase appetite. On the other hand, colors that are considered cool or soft are color choices that are closely related to blue, green, and violet (Mwangi 2010).

Research on color and its effect on human psychology has been relatively widely 
done, for example by Hauff (2019), Elliot \& Maier (2014), and Adam \& Ali (2014). The combination of yellow and green, or reddish and violet gives the impression of warm or cool. The difference in the impact from color will depend on what color dominates. White, black and gray colors are considered neutral (Singh \& Srivastava 2011). Vegetables and spices, for example red chili pepper which has a perception of heat, sharp, and spicy in taste. In the same way, customers will also have the perception that green will be better visualized, so that it is perceived as a delicious dish. The selection of color plates also determines the success of a tantalizing food dish (Mwangi 2010).

The texture of selected ingredients such as flavor and seasoning is an important element. The taste is certainly the most important factor in a food dish, using ingredients that are fresh and taste delicious, display a food will increase naturally. For the cooks, the technique can be an important factor to be able to keep a food dish still has a texture that is good. Food texture includes physical characteristics felt by the five senses. The texture of food should be able to meet a variety of criteria, ranging from taking into account the texture of the food itself so that it sounds at the time of being bitten and chewed by the customer, the microstructure of the material used, the movement of the muscles used during chewing food and swallowing, as well as the acceptability of customer itself (Civille 2010).

Food textures provide sensory signals to consumers, where most of these signals stimulate consumer responses to good and bad, because of the expected pleasure, from puddings and ice cream to crackers and crispy snacks. One of the important roles that the texture factor plays is the success of the product is an indication of the freshness and stability of the food product. The mechanical properties of food textures, such as hardness, compactness, crispness, suppleness, and solidity, are easy indicators of product freshness and usability. Although texture is often considered secondary because of the taste in evaluating the success and acceptability of the product, the texture will give results on a scale for customer satisfaction, if the texture does not meet consumer expectations then they will be disappointed (Civille 2010).

The plates used in serving a food presentation can be distinguished by shape or size. In addition to colors, the plate also presents a variety of different shapes. Certain restaurants use a variety of circle-shaped, triangle and rectangular plates that are matched to the composition of the food. Matching the shape of the plate with the dish may seem too fancy for many visitors and will have an expensive perception in a food. The selection of dishes that are served will certainly be a key so that food looks beautiful when served. For example, if the portion of food composition varies, it requires a wider plate size so that the food does not look full in one plate. Otherwise, if the food composition is only a little, the cooks must be able to place it on a plate that matches its size. Aesthetics on a plate should be able to look beautiful, as a result all components of the selection of raw materials used can be a beautiful combination in a food display (Spence et al. 2016).

Stewart \& Goss (2013) stated that the color and shape in the appearance of food on a plate determines a person's perception in the assessment of the quality of food served. Customers' perceptions of a white and round plate, or black and square plates, will be very different. The customer's basic assessment will be relatively increased with white and round plates instead of using black and square plates, at least in terms of "sweet" taste and "delicious" flavor image. By knowing this information, the chef should certainly modify the image of the taste "delicious" and "sweet" when using white plates (Stewart \& Goss 2013).

The balance and complexity of good food arrangement on a plate also tends to add the appeal of a food for customers. Based on articles from Chef Resources (2015) and Unilever Food Solutions (2016), simple geometric shapes need to be considered in 
platting a dish. The food layout above a plate needs to follow a simple geometric shape, such as; lines, arc, and circles.

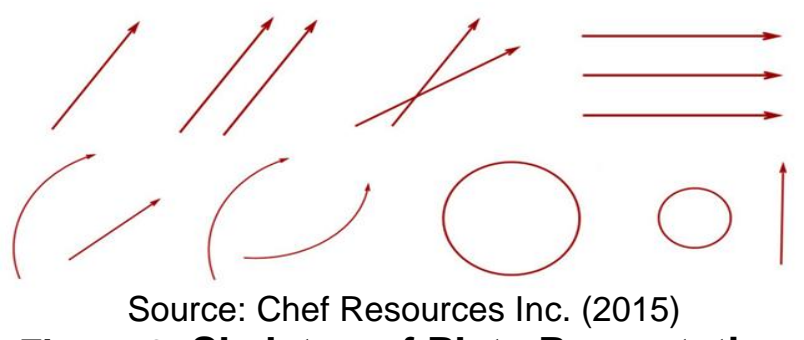

Figure 3. Skeleton of Plate Presentation

The research results of Collinge (2017) revealed the visualization of a food display has an impact as a communication tool from the restaurant to the customer. The food display has the ability to spread the power of the brand that wants to be created (Moteset al. 2008, Spence et al. 2016). Appearance serves to have the " wow " effect that is able to change the perception of flavor. Therefore, an attractive visual appeal will give a good first impression for them to achieve satisfaction when it comes to a restaurant (Ray 2015).

The quality of food in a restaurant is certainly very important to ensure the level of customer satisfaction in a restaurant (Al-Tit 2015, Ha \& Jang 2010, Rozekhi et al. 2016). In a study conducted by Al-Tit (2015), food quality becomes the main factor someone decided to come to a restaurant. However, components are more value to offer to customers, such as; quality service, appropriate price, and a good physical or atmospheric restaurant, will further boost up the decision of a restaurant selection. For the owner of the restaurant, hiring the right cooks in line with the type/ kind of menu offered is a way of being able to offer a good quality of food to customers. According to Ha \& Jang (2010), factors that influences the quality of the food is the taste of the food itself, the varied restaurant menu, and the nutritional content.

The taste of food would be a major attribute in the effort to establish the level of customer satisfaction (Rozekhi et al. 2016). Without the presence of a good sense of food, then the relative customers will not choose to return to the restaurant. With the presence of social media, this experience will be directly widespread in mass. On the other hand, if the customer likes the taste of a food dish in a restaurant, then the customer will automatically disseminate this fact. The challenge of restaurants is of course to maintain the consistency of the image of taste.

Kotler \& Armstrong (2014), stated that the completeness of the product is relatively important to increase the variety of offers to be owned, used, and/ or consumed by customers. Variations of a product in a restaurant also plays an important role, ranging from the taste, size, quality, price, atmosphere, as well as the availability of a selection of food products in a restaurant (Tjiptono 2014). Therefore, a restaurant should be able to present a varied and innovative menu to meet customer desires (Putra, Saroso, \& Anantadjaya 2015).

People has increasingly had information about nutrition at this time. The level of public awareness is getting better along with technological developments where information is more easily obtained and learned (Pulos \& Leng 2010). Referring to the research results from Munada (2017), and Pardede, Rosdiana, \& Christianto (2017), the amount of obesity jumped from $12 \%$ to $21 \%$ in the $2007-2010$ in Indonesia. According to their research, there are more than 30 million Indonesians who are overweight. In this case, there needs to be socialization to the public regarding the role and impact of 
sugar, sodium, caffeine, and cholesterol on weight gain. With this condition, the restaurant needs to also ensure the nutritional content in food dishes to customers (Pardede, Rosdiana, \& Christianto 2017, Munada 2017) This is supported by the results of research from Vijayakurmaran \& Amalina (2018) which states that information about food nutrition offered to customers has a positive impact on increasing customer satisfaction (Thomas Jr \& Mills 2006).

Customer satisfaction is the main factor that becomes the basis whether the customer will make a repurchase or not (Exhibit, Moizer, \& Pettinicchio 2010). Customer satisfaction itself is a merger between the analysis of the difference between expectations and actual reality (Gustafsson, Johnson, \& Roos 2005, Indra \& Anantadjaya 2011, Oliver 1999). Business owners have a responsibility to always be able to meet the customer (Ghimire 2012). Customer satisfaction has an impact on the power of mouth from the customer itself to others (Okumu 2012, Wirtz \& Lovelock 2016). On the other hand, customer dissatisfaction will give customers the opportunity to start glancing at the other players available in the market.

The level of customer satisfaction is considered to be a major factor in the hospitality industry. However, the ability to be able to conduct accurate assessments of the level of customer satisfaction is certainly a challenge (Hsu \& Wu 2013, Reid \& Bojanic 2009). Satisfaction of customers who come to the restaurant will have a positive impact on the customer's decision to repurchase (Cameran, Moizer, \& Pettinicchio 2010, Shock, Bowen, \& Stefanelli 2004). Figure 4: Perceived Quality of Service explained that consumers assess a level of satisfaction of its by comparing between the expectations of the experience of the real that is acceptable.

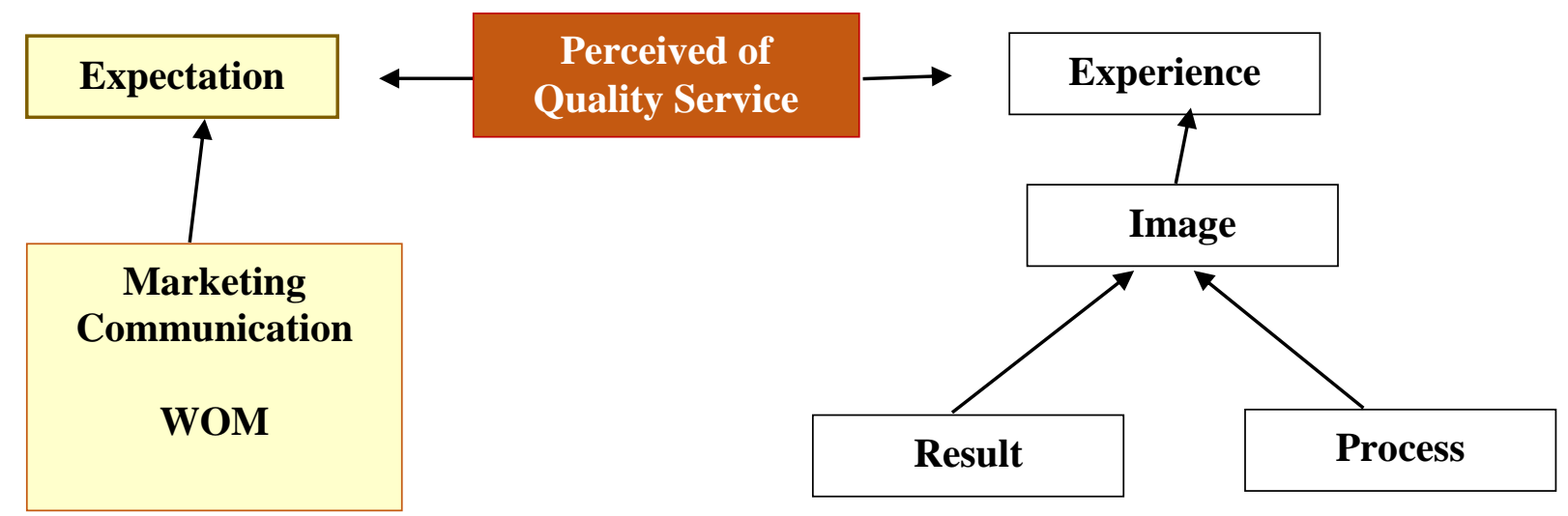

Figure 4. Quality of Service Perceived

Source: Okumu (2012)

The following table are some of the previous studies related to this research topic.

Table 1. Prior Research Results

\begin{tabular}{|c|c|c|c|}
\hline Title \& Author & Variable & Research result & $\begin{array}{l}\text { Differences from the } \\
\text { research carried out }\end{array}$ \\
\hline $\begin{array}{l}\text { Food Presentation } \\
\text { General (Caribbean } \\
\text { Hotel Association } \\
\text { 2003) }\end{array}$ & $\begin{array}{l}\text { Food } \\
\text { Presentation }\end{array}$ & $\begin{array}{l}\text { Elements of food } \\
\text { presentation that must be } \\
\text { considered }\end{array}$ & $\begin{array}{l}\text { Discussing element of } \\
\text { the presentation of the } \\
\text { food and the } \\
\text { corresponding } \\
\text { relationships between } \\
\text { elements }\end{array}$ \\
\hline $\begin{array}{l}\text { The Roles of the } \\
\text { Physical } \\
\text { Environment, Price }\end{array}$ & $\begin{array}{l}\text { Physical } \\
\text { Environment, } \\
\text { Price }\end{array}$ & $\begin{array}{l}\text { The physical } \\
\text { environment aspect, which } \\
\text { consists of spatial layout, }\end{array}$ & $\begin{array}{l}\text { Discussing food } \\
\text { presentation, but is } \\
\text { incorporated in }\end{array}$ \\
\hline
\end{tabular}




\begin{tabular}{|c|c|c|c|}
\hline Title \& Author & Variable & Research result & $\begin{array}{l}\text { Differences from the } \\
\text { research carried out }\end{array}$ \\
\hline $\begin{array}{l}\text { Perception, and } \\
\text { Customer } \\
\text { Satisfaction in } \\
\text { Determining } \\
\text { Customer Loyalty in } \\
\text { the Restaurant } \\
\text { Industry (Han \& Ryu } \\
\text { 2009) }\end{array}$ & $\begin{array}{l}\text { Perception, } \\
\text { Customer } \\
\text { Satisfaction, } \\
\text { Customer } \\
\text { Loyalty }\end{array}$ & $\begin{array}{l}\text { ambient conditions, } \\
\text { decoration \& artifacts, has } \\
\text { the biggest impact on } \\
\text { customer satisfaction, } \\
\text { rather than food prices. } \\
\text { Included in the " artifacts " } \\
\text { are food presentations } \\
\text { from restaurants }\end{array}$ & $\begin{array}{l}\text { the artifacts of a } \\
\text { restaurant }\end{array}$ \\
\hline $\begin{array}{l}\text { Effects of Service } \\
\text { Quality and Food } \\
\text { Quality: The } \\
\text { Moderating Role of } \\
\text { Atmospherics in an } \\
\text { Ethnic Restaurant } \\
\text { Segment (Ha \& } \\
\text { Jang 2010) }\end{array}$ & $\begin{array}{l}\text { Waiter } \\
\text { Quality, Food } \\
\text { Quality }\end{array}$ & $\begin{array}{l}\text { This study revealed that } \\
\text { food and service quality } \\
\text { has a significant impact in } \\
\text { influencing customer } \\
\text { satisfaction. }\end{array}$ & $\begin{array}{l}\text { Discussing the quality of } \\
\text { service and food to the } \\
\text { atmosphere of the } \\
\text { restaurant }\end{array}$ \\
\hline $\begin{array}{l}\text { Importance of } \\
\text { Customer } \\
\text { Satisfaction in } \\
\text { Waskia } \\
\text { Restaurant (Okumu } \\
\text { 2012) } \\
\text { Factors of Food }\end{array}$ & $\begin{array}{l}\text { Restaurant } \\
\text { Performance, } \\
\text { Customer } \\
\text { Satisfaction, } \\
\text { Quality } \\
\text { Management } \\
\text { Food Quality, }\end{array}$ & $\begin{array}{l}\text { Customers who are } \\
\text { satisfied with the } \\
\text { restaurant's performance } \\
\text { in terms of taste, portion, } \\
\text { and presentation. }\end{array}$ & $\begin{array}{l}\text { Discussing the role of } \\
\text { food taste, portions and } \\
\text { presentation in relation to } \\
\text { restaurant performance }\end{array}$ \\
\hline $\begin{array}{l}\text { Dimension Affecting } \\
\text { Customer } \\
\text { Satisfaction in } \\
\text { Family } \\
\text { Restaurant (Sahari, } \\
\text { Basir, \& Jangga } \\
\text { 2012) } \\
\text { Factors Influencing } \\
\text { Dining Experience }\end{array}$ & $\begin{array}{l}\text { Food Pricing, } \\
\text { Food } \\
\text { Portioning, } \\
\text { Food } \\
\text { Presentation, } \\
\text { Customer } \\
\text { Satisfaction }\end{array}$ & $\begin{array}{l}\text { The order of aspects that } \\
\text { affect the level of } \\
\text { customer satisfaction in a } \\
\text { restaurant is food quality, } \\
\text { food presentation, food } \\
\text { portions and food prices }\end{array}$ & $\begin{array}{l}\text { Discussing's a number of } \\
\text { dimensions of food to the } \\
\text { level of customer } \\
\text { satisfaction to know the } \\
\text { ranking order }\end{array}$ \\
\hline $\begin{array}{l}\text { on Customer } \\
\text { Satisfaction in Fast } \\
\text { Food } \\
\text { Restaurant (Yong, } \\
\text { Afternoon, Lok \& } \\
\text { Kuan 2013) } \\
\text { Plating Manifesto }\end{array}$ & $\begin{array}{l}\text { Food } \\
\text { Presentation, } \\
\text { Customer } \\
\text { Satisfaction }\end{array}$ & $\begin{array}{l}\text { Aspects that affect } \\
\text { customer satisfaction } \\
\text { in fast food restaurants. }\end{array}$ & $\begin{array}{l}\text { Discussing food } \\
\text { presentations on } \\
\text { customer satisfaction }\end{array}$ \\
\hline $\begin{array}{l}\text { (II), The Art and } \\
\text { Science of } \\
\text { Plating (Spence, } \\
\text { Piqueras-Fiszman, } \\
\text { Michel, \& Deroy } \\
\text { 2014) }\end{array}$ & $\begin{array}{l}\text { Food } \\
\text { Presentation }\end{array}$ & $\begin{array}{l}\text { The art of presenting } \\
\text { food and aspects that } \\
\text { need attention (garnish). }\end{array}$ & $\begin{array}{l}\text { Discussing the } \\
\text { techniques and art of } \\
\text { food presentation } \\
\text { specifically }\end{array}$ \\
\hline
\end{tabular}

History records that Japan was the first country to attempt to carry a food model or food sample which is a replica of food served by restaurants, and displayed in store since the 1920s (McCurry 2018). At that time, customers had difficulty in imagining food that was ordered so that finally Japan began displaying replicas of the available food. With the display of food replicas, the restaurant experienced a drastic increase in sales. 
According to some researchers, such as; Collinge (2017), Motes, Malach \& Kozhevnikov (2008), Spence, Okajima, Cheok, Petit \& Michel (2016), and Ray (2015), good composition in the food display needs to meet a balance between the selection of the right material components (Unilever Food Solutions 2016), matching and harmonious colors (Adam \& Ali 2014, Elliot \& Maier 2014, Hauff 2019, Mwangi 2010, Putra, Saroso, \& Anantadjaya 2015, Singh \& Srivastava 2011), textures that fit the criteria/types (Civille 2010, Haugaard 2015; Jeltema, Beckley, \& Vahalik 2015), the right shape (Spence, Okajima, Cheok, Petit, \& Michel 2016, Stewart \& Goss 2013), and beautiful layout (Chef Resources Inc. 2015, Unilever Food Solutions, 2016). A world business group records of formal procedures regarding the presentation of food (Caribbean Hotel Association, 2003). This formal handbook on food presentation is supported by further research by Han \& Ryu (2009), Sahari, Basir \& Jangga (2012), Yong, Siang, Lok \& Kuan (2013), and Spence, Piqueras-Fiszman, Michel \& Deroy (2014). Thus, a hypothesis can be formulated as follows; H1: Food display has a positive influence on customer satisfaction at the restaurant Tutup Panci Bistro.

The drastic increase mentioned above, must also be accompanied by food quality (McCurry 2018). Therefore, in addition to the formal procedures manual regarding food presentation, research on food quality and customer satisfaction, as a development of McCurry's research (2018), also conducted by other researchers, such as Han \& Ryu (2009), Ha \& Jang (2010), Okumu (2012), Sahari, Basir \& Jangga (2012), Yong, Siang, Lok \& Kuan (2013). So that, a hypothesis can be formulated as follows; H2: Food quality has a positive influence on customer satisfaction at the restaurant Tutup Panci Bistro.

Both of these hypotheses can be shown through the following illustrations which shows the linkage between variables and sub-variables used in this study, as shown in Figure 5: Research Model

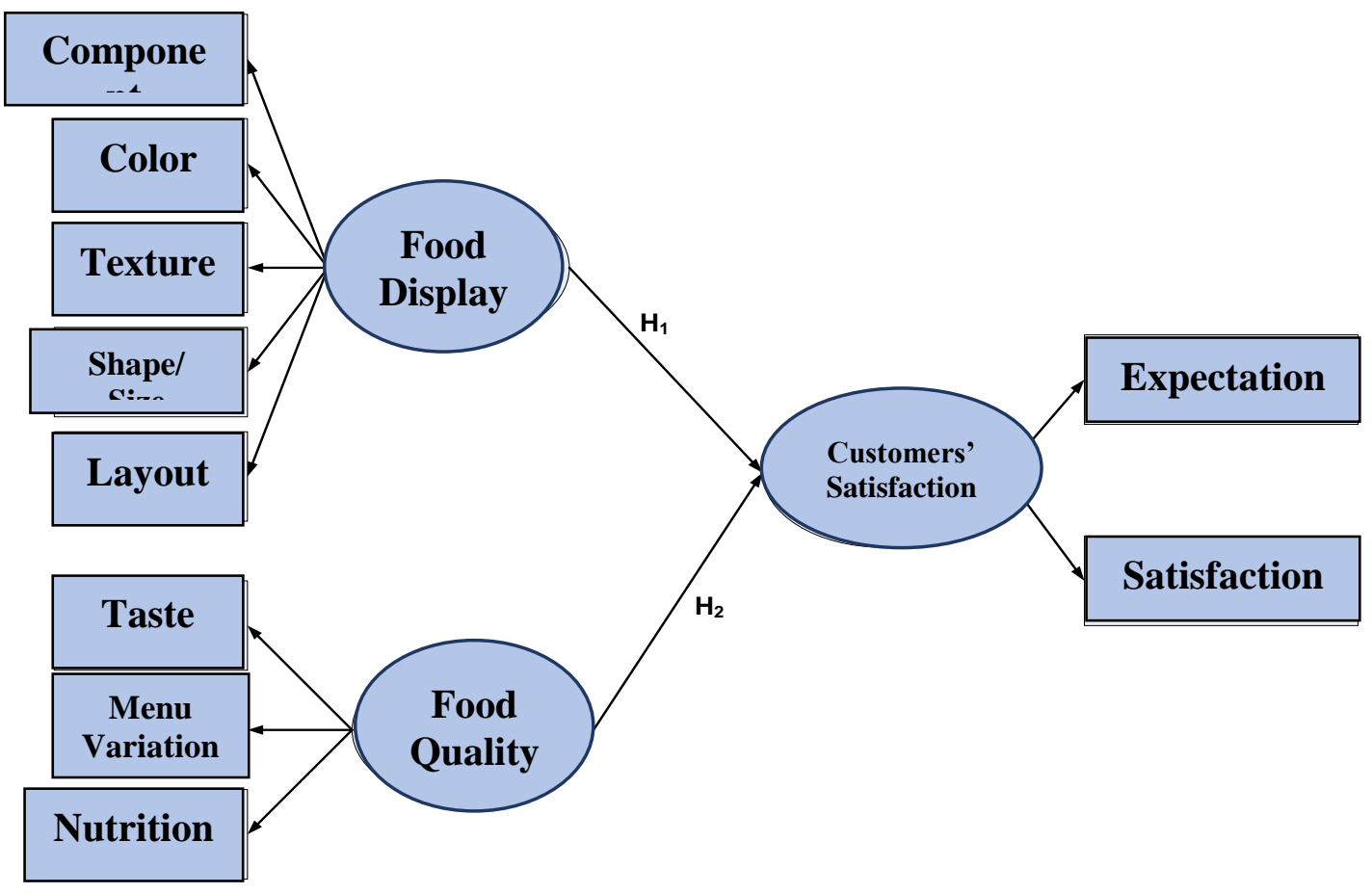

Figure 5. Research Model

\section{RESEARCH METHODS}

This study uses quantitative research that carries structural equation modelling (Arbuckle 2011, Ghauri \& Gronhaug 2005, Mustafa \& Wijaya 2012, Sarwono 2012) as a 
tool for data analysis, which combines factor analysis (Field 2005) and track analysis (Ghozali, Model Equations Structural: Concepts and Applications with the AMOS Program ves. 5.0 2004), either directly or through intermediate variables.

The sampling method used in this study is a combination of cluster and convenience sampling (Anantadjaya \& Nawangwulan 2018, Cooper \& Schlinder 2011, Sekaran \& Bougie 2009). Cluster sampling is needed to build the focus on restaurant research in the BSD City area in South Tangerang, where there are many other restaurants with various types of menus so that it can be focused on a restaurant called Tutup Panci Bistro, which offers a fushion menu by combining Indonesian menu with western . Considering that this type of fushion food is not widely known by the people in this area, the number of visitors at Tutup Panci Bistro is relatively unstable and cannot be estimated. With these conditions, this study also requires convenience sampling to be able to engage customers who visit the restaurant, either in the day, afternoon, or evening.

By using the basic PHStat, calculation as shown in Table 2 : Determination of the Sample Size, which estimated that only $50 \%$ of the population is considered to be correct in providing its response accurately, with a tolerance of error of $10 \%$, and still reaching the $95 \%$ confidence level, the minimum required sample is 97 respondents. By comparison, the basic calculation of samples is also obtained from Raosoft. By showing the minimum number of 96 samples needed to maintain a maximum of $10 \%$ error rate, but still achieving 95\% confidence level. Referring to this minimum number of samples, both with PHStat (97 respondents), or Raosoft (96 respondents), this study uses 100 restaurant visitors as respondents.

Table 2. Determination of Sample Size with PHStat

\begin{tabular}{lc}
\hline Estimate of True Population & 0.5 \\
Sampling Error & 0.1 \\
Confidence Level & $95 \%$ \\
Minimum Sample Size & $\mathbf{9 7}$
\end{tabular}

Source: Pearson Education (2018)

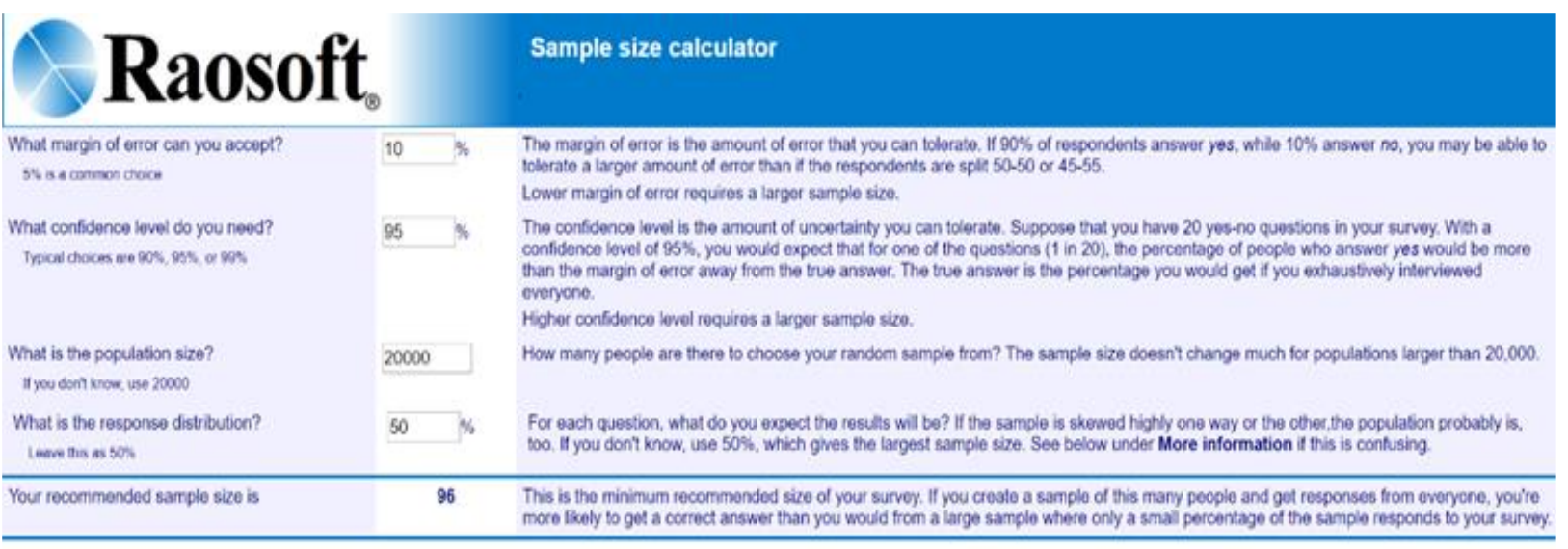

Online surveys with Vovici have completion rates of $66 \%$ !

Alternate scenarios
\begin{tabular}{r|c|c|c|c|c|c|c|}
\hline With a sample size of & 100 & 200 & 300 & With a contidence level of & 90 & 95 & 99 \\
Your margin of error would be & $9.78 \%$ & $6.89 \%$ & $5.62 \%$ & Your sample size would need to be & 68 & 96 & 165 \\
\hline
\end{tabular}

Figure 6. Determination of Sample Size with Raosoft

Source: Raosoft. Inc. (2004) 


\section{RESULT AND DISCUSSIONS}

Since August 2016, with a capacity of 80 seats, Tutup Panci Bistro located in Anggrek Loka, BSD City, South Tangerang has families, office workers, university students and students as their target. This restaurant provides the type of food that is a combination of Indonesian cuisine with western dishes, or better known by the Indonesian Fusion Casual Dining. Some of the main menu of Tutup Panci Bistro are; Rendang Beef Taco, Balinese Chicken Aglio Olio, Balinese Mixed Rice, Modernist Ice Pisang ljo, and Cendol Pannacotta. While in terms of drinks, they serve coffee, mocktail, milkshake, and several tea variants. The price range for the food is $\mathrm{Rp} .23 .000$ to Rp. 65.000 , and beverage is Rp. 8.000 to Rp. 35.000 .

Out of a total of 100 respondents, the following is their profile; (1) $68 \%$ of respondents are women, (2) 13\% of respondents are younger than 20 years, (3) $91 \%$ of respondents are entrepreneurs, employees, and housewives, and (4) $15 \%$ of respondents make purchases of less than Rp50000 per visit. From the combination of respondents' profiles in this study, a conclusion can be drawn where the majority of visitors are women who are over 20 years old. Their job is as a housewife, businessman and office employee around the Tutup Panci Bistro location, such as; telecommunications companies, hospitals, schools, hotels/ motels, including employee boarding houses, and residential complex. As well, the majority of visitors make purchases more than Rp. 50.000. From such a profile, which originated from 100 respondents, it can be used as a basic reference to re- evaluate the marketing strategy concept of Tutup Panci Bistro. Based on the results of the respondents' profile, then Tutup Panci Bistro needs to ensure that the entire package offered in the menu and its presentation must be aligned with the visitors.

Reliability and validity testing in this study was conducted by taking attention into several stages of the process. Table 3: Reliability \& Validity Test Results showed the level of reliability and validity of the data, in general, it is already qualified because internal consistency was achieved (Cooper \& Schlinder 2011, Sekaran \& Bougie 2009, Sarwono 2012, Sugiyono 2017, Ghozali 2004, Hanover College, nd).

Table 3. Reliability \& Validity Test Results

\begin{tabular}{lcccc}
\hline Test Type & Pre-Testing & Amount of data & Post Testing & Amount of data \\
\hline Reliability & 0.940 & 30 & 0.927 & 100 \\
Validity & .697 & 30 & 0,900 & 100 \\
\hline
\end{tabular}

Source: IBM SPSS Amos (2018b)

From Table 4, it can be seen the Item-Total Statistics that the value of Cronbach Alpha (if item deleted) already meets the requirements (Ghozali 2009, Hanover College n.d, Sarwono 2012, Sugiyono 2017). All items are listed in the table below shows the reduction in the overall value of Cronbach Alpha if there are items that are not used. In particular, it can be noted that the nutrients, if not used, still giving effect to the reduction in the value of Cronbach Alpha, albeit small. This is because the content of the Pearson correlation value is also relatively small, amounting to 0.36 , but still has a high significance rate of $1 \%$, as shown in the Table 5: Pearson Correlation. The role of nutrition is also supported by the results of interviews (Fernando 2018), where the nutritional content has a special role in the level of quality of a food. 
Table 4. Item-Total Statistics

\begin{tabular}{lccccc}
\hline & $\begin{array}{c}\text { Scale Mean if } \\
\text { Item Deleted }\end{array}$ & $\begin{array}{c}\text { Scale } \\
\text { Variance if } \\
\text { Item Deleted }\end{array}$ & $\begin{array}{c}\text { Corrected } \\
\text { Item-Total } \\
\text { Correlation }\end{array}$ & $\begin{array}{c}\text { Squared } \\
\text { Multiple } \\
\text { Correlation }\end{array}$ & $\begin{array}{c}\text { Cronbach's } \\
\text { Alpha if Item } \\
\text { Deleted }\end{array}$ \\
\hline Component & 34,870 & 31,326 & .761 & .638 & .912 \\
Color & 34,800 & 32,040 & 703 & .593 & .915 \\
Texture & 34,880 & 32,193 & 705 & .545 & .915 \\
Shape & 34,875 & 31,936 & .686 & .561 & .916 \\
Location & 34,850 & 30,634 & .777 & 702 & .911 \\
Taste & 34,840 & 32227 & 659 & 594 & .918 \\
Menu & 34,825 & 32,199 & .675 & .511 & .917 \\
Nutrition & 34,940 & 32,921 & .518 & .419 & .926 \\
Expect & 34,860 & 31,137 & .775 & .720 & .911 \\
Satisfaction & 34,740 & 30,644 & .825 & .772 & .908 \\
\hline
\end{tabular}

Source: IBM SPSS Amos (2018b)

From the correlation of Pearson, as shown in Table 5: Pearson Correlation, the level of correlation between variables is considered eligible because it is within a distance that is still considered useful and able to contribute (Mustafa \& Wijaya 2012, Sarwono 2012, Sugiyono 2017, Ghozali 2009). Although nutrients have the smallest correlation value, nutrition remains used in the study is due to a level of trust that is high at $99 \%$. In addition, based on the results of interviews (Fernando 2018), it was also stated that nutrient content has a strong relationship to support the quality of a food. Thus, although the value of the correlation of nutrients is relatively minimal, but with a high level of trust and supported by the results of the interview, nutrients are still being used in subsequent data analysis processes.

Table 5. Pearson Correlation

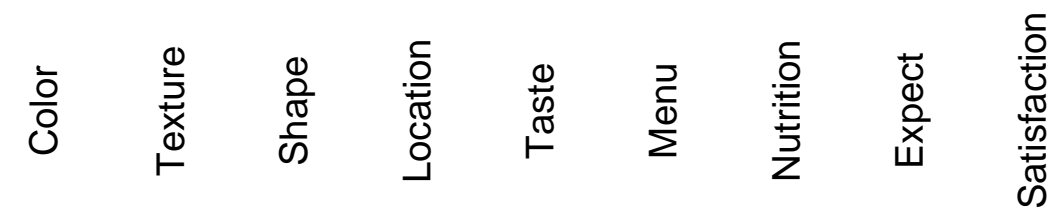

\begin{tabular}{cccccccccccc}
\hline \multirow{2}{*}{ Component } & $\begin{array}{c}\text { Pearson } \\
\text { Correlation }\end{array}$ & $.585^{* *}$ & $.568 *$ & $.648 *$ & $.999^{* *} .494^{* *} .5211^{* *} .360 *$ & $.696 *$ & $* 681 * *$ \\
& Sig. (2-tailed) & .000 & .000 & .000 & .000 & .000 & .000 & .000 & .000 & .000 \\
\hline
\end{tabular}

Source: IBM SPSS Amos (2018b)

Figure 7: Structure Equation Model (SEM) explains the linkage of indicators and variables in this study; The results obtained indicate that the visualization of food display to customer satisfaction has a value of $90 \%$. This value implies that a $1 \%$ increase made by restaurants on the visualization of food appearance gives a $90 \%$ increase in the level of customer satisfaction. This finding is in line with the results of the interview where it was stated that with the presence of the internet, people began to enjoy a meal that originated from the visualization of its appearance (Fernando 2018). From the subvariables used to measure the visualization of food display, the food layout has the power to explain the lowest visualization of food display, $60 \%$, followed by a texture of $78 \%$. The combination of food components, colors, shapes and sizes has the power to explain at least $80 \%$. As stated by Indra Ketaren (Dhetira 2016), visualization of food display triggers customer experience in every single contact point as the customer senses are given concurrent stimulation. As in previous study conducted by Yong, 
Siang, Lok \& Kuan (2013), the appearance of a food dish can have a positive impact on customers when enjoying the food.

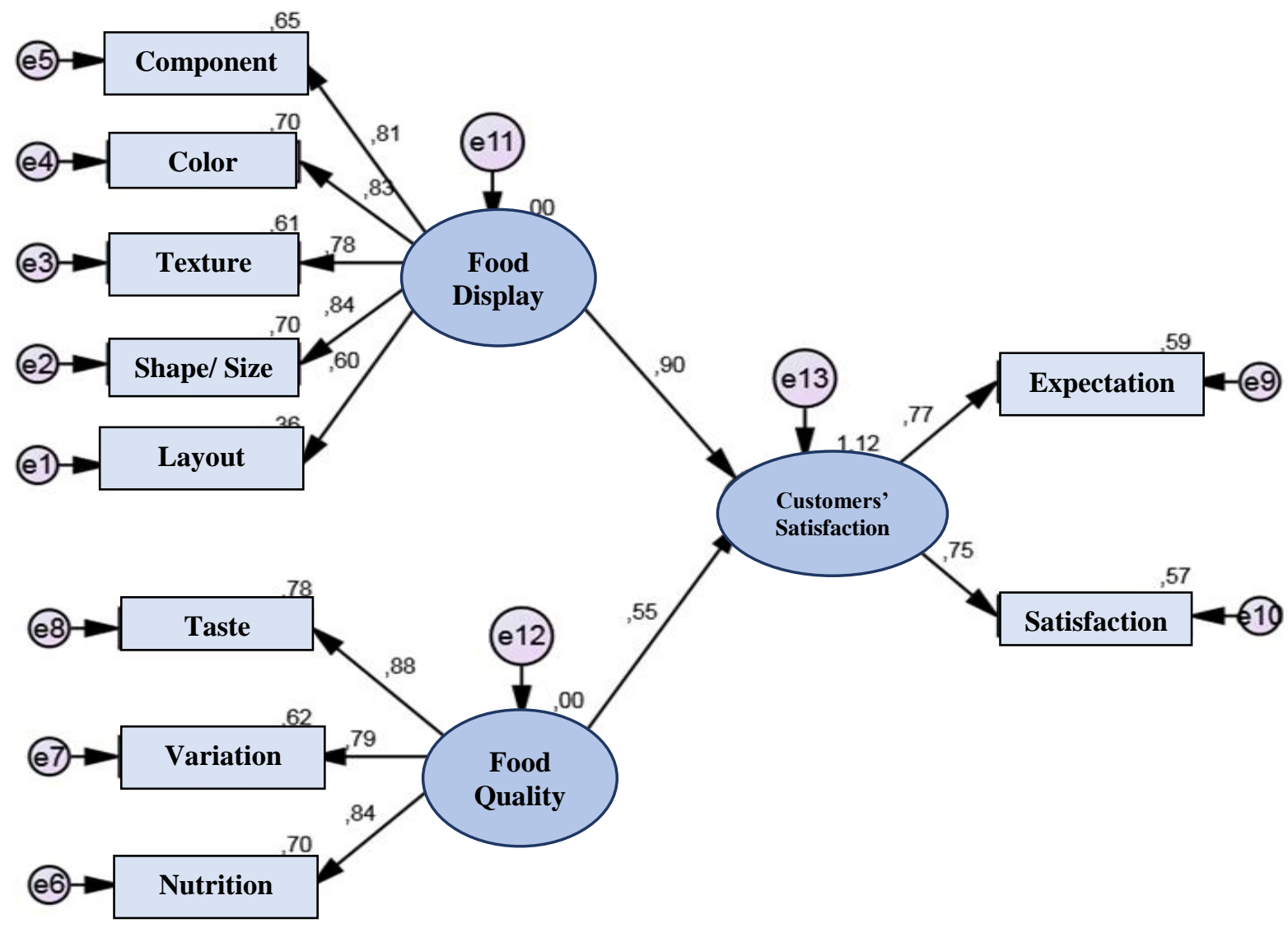

The balance of food components, including sauces, is a factor that must be considered in a food display visualization. The results of this study show that the food component has $81 \%$ power to be able to explain the visualization of food display. This is supported by the results of previous studies conducted by Spence, Piqueras-Fiszman, Michel \& Deroy (2014), where the balance of good and right food composition will look more attractive before being enjoyed by customers. The results of the analysis show that food color has $83 \%$ strength to be able to explain food display visualization. Definitely, a combination of food colors can increase the food tastes of the customers. This has been proven by Mwangi (2010). However, too much color mixing is displayed in a food dish, the customer focus will be disrupted (Motes, Malach, \& Kozhevnikov, 2008; Singh \& Srivastava 2011; Stewart \& Goss 2013).

Food textures has the power to be able to explain food display visualizations of $78 \%$. This food texture has a relatively big impact after customers taste the food (Civille 2010), such as; the meat must be tender and still juicy. The combination of the shape and size of a plate and the food served has the power to be able to explain by $84 \%$ of the visualization of food display. The results of this study are in line with previous studies conducted by Peter Stewart \& Erica Goss (2013). Aesthetics on a plate should look beautiful, so that it can display a combination of beautiful display visualization (Spence, Okajima, Cheok, Petit, \& Michel 2016).

The food layout on a plate has the power to explain food visualization by $60 \%$. Considering the layout of the material components in a neat plate and creating a simple presentation and can follow simple geometric shapes, such as lines, arcs, and circles a creativity that must be owned by the chefs so as to create the layout of a food that is visually visible both in their eyes (Chef Resources Inc. 2015). 
Quality of food impacted positively by $55 \%$ on the level of customer satisfaction. By referring to research from $\mathrm{Ha} \&$ Jang (2010), which said that the factors that can improve food quality is food taste, varied menus, and nutrient content in a food, the results of the analysis showed that variations in food or varied menus has the power to be able to explain food quality by $79 \%$, followed by nutrients by $84 \%$, and taste by $88 \%$. With regard to the 3 factors, customers visit a restaurant not just for eating, but also for eating delicious food, with good nutrition, and adequate choice of food variations. This finding is in line with the results of research from Al-Tit (2015). These results relatively indicate that Tutup Panci Bistro already has these 3 factors in an effort to improve the quality of its food.

Regarding the indicators used in this study to try to measure food quality, the taste of food has $88 \%$ power to be able to explain food quality. In the event of an increase in food taste, then the quality of food will also be pushed up better. The finding is in line with previous studies conducted by Stewart \& Goss (2013). This shows that the taste of food still plays an important role for a food in a restaurant.

The value of the menu variations on food quality is $79 \%$. This value implies that menu variations have a power of $79 \%$ to be able to explain the quality of food in a restaurant. The more variations on the menu, the better the quality of the food according to customer ratings. This possibility provides the basic for customers to return to a restaurant because of the varied food and menu choices. With such menu variations, customers don't need to think about other places because a restaurant is able to offer a one-stop-dining experience. When customers want menu $\mathrm{A}$, and later want menu $\mathrm{B}$, a restaurant still has the variation. In addition to the main menu/ main course, it also refers to the choice of appetizer / snack, dessert, diversity of coffee drinks, tea, mocktail, and milkshakes. This result is in line with previous research which says that menu variations are the basis for better offers to customers (Hsu \& Wu 2013, Munada 2017, Pulos \& Leng 2010, Putra, Saroso, \& Anantadjaya 2015, Thomas Jr \& Mills 2006).

The nutritional content in a food dish shows a value of $84 \%$. This value implies that the nutritional content has $84 \%$ strength to be able to explain the quality of food. In the event of improvement of nutritional content, the quality of food is perceived better by the customer. Referring to an article that writes about the increase in obesity in Indonesia, public awareness of food has also increased (Darmayana 2017), especially for sugar, sodium, caffeine, and cholesterol. It is also in line with statements from Pulos \& Leng (2010), and Vijayakurmaran \& Amalina (2018), where the nutritional content has a positive impact on food quality.

Customer satisfaction is one of the keys to organizational success. Without the presence of satisfied customers, the organization cannot survive. The illustration in Figure 9: Value of Customer Satisfaction Indicators shows that the two indicators used show positive values. Indicator of customer expectations / expectations has a value of $77 \%$. This implies that expectations have the power to explain customer satisfaction by $77 \%$. When visiting a restaurant, customers arrive with a number of expectations from various sides. Expectations arising from customers can come from information that has been received previously, either through word-of-mouth, social media (Bennet 2017), other people's stories, or their own experiences. This shows the role of a restaurant to be able to create an expectation in the minds of prospective customers, so they want to be able to realize these expectations into a reality by visiting the restaurant. The task of the restaurant is of course trying to maintain the creation of a positive experience in every transaction process; starting from the time of parking, entering the room, ordering, while enjoying a meal, and when making payments to leave the location of the restaurant. In each transaction process, the restaurant should be able to ensure the 
creation of a positive experience (Dhetira 2016).

The indicator of actual satisfaction/customer statement refers to the actual experience received by the customer and that experience is compared with the customer's expectations in the beginning. When the actual experience exceeds customers' expectations, the actual satisfaction level/reality will be positive, and vice versa becomes negative when the initial customer expectations cannot exceed the actual experience received and felt by the customer (Okumu 2012). The results of this study indicate a value of $75 \%$, which implies that actual/ reality satisfaction has the power to be able to explain the level of customer satisfaction. The increasing customers' actual satisfaction of a food display visualization, the level of customer satisfaction increases as well.

The results of the model in this study are as follows;

Table 6. Goodness of Fit

\begin{tabular}{|c|c|c|c|c|}
\hline Criteria & $\begin{array}{c}\text { Based on } \\
\text { Schumacker } \\
\text { and } \\
\text { Lomax (2004) \& } \\
\text { Wijaya (2009) }\end{array}$ & $\begin{array}{c}\text { Based on } \\
\text { Ghozali (2004), Santoso (2009) }\end{array}$ & $\begin{array}{l}\text { Value } \\
\text { Model }\end{array}$ & Goodness Fit \\
\hline $\begin{array}{l}\text { CMIN / df } \\
\text { (normed chi } \\
\text { square) } \\
\text { RMSEA }\end{array}$ & $\begin{array}{l}\text { CMIN / df } \leq 2= \\
\text { Good }\end{array}$ & CMIN / df $\leq 5=$ Good & 5,240 & Good \\
\hline $\begin{array}{l}\text { (Root mean } \\
\text { square error of } \\
\text { approximation) }\end{array}$ & $\begin{array}{l}\text { RMSEA } \leq \\
0: 08=\text { Good }\end{array}$ & RMSEA $\leq 5=$ Good & 0.207 & Good \\
\hline $\begin{array}{c}\text { GFI } \\
\text { (Goodness Fit } \\
\text { Index) }\end{array}$ & $\begin{array}{l}\text { GFI value close } \\
\text { to } 1=\text { Good }\end{array}$ & GFI value close to $1=$ Good & 0.829 & Good \\
\hline $\begin{array}{c}\text { AGFI } \\
\text { (Adjusted } \\
\text { goodness of } \\
\text { Fit Index) }\end{array}$ & $\begin{array}{l}\text { AGFI value } \\
\text { close to } 1 \\
=\text { Good }\end{array}$ & AGFI $\geq 0.09=$ Good & 0.714 & Good \\
\hline $\begin{array}{l}\text { TLI } \\
\text { (Tucker Lewis } \\
\text { Index) }\end{array}$ & $\begin{array}{l}\text { TLI value close } \\
\text { to } 1=\text { Good }\end{array}$ & TLI $\geq 0: 09=$ Good & 0.756 & Good \\
\hline $\begin{array}{c}\text { CFI } \\
\text { (Comparative } \\
\text { Fit Index) } \\
\text { NFI }\end{array}$ & $\begin{array}{l}\text { CFI Value close } \\
\text { to } 1=\text { Good }\end{array}$ & $\begin{array}{c}\text { CFI value approaching } 1 \\
=\text { Good }\end{array}$ & 0.821 & Good \\
\hline $\begin{array}{l}\text { (Normal Fit } \\
\text { Index) }\end{array}$ & - & NFI $\geq 0: 09=$ Good & 0.792 & Good \\
\hline
\end{tabular}

Source: Arbuckle (2011), Anantadjaya \& Nawangwulan (2018); Santoso (2009); Ghozali, Structural Equation Model: Concepts and Applications with the AMOS Program ves. 5.0 (2004); Mustafa \& Wijaya, (2012); Schumacker \& Lomax (2004)

From the existing standard reference according to Ghozali (2004), Santoso (2009), Wijaya (2009), Mustafa \& Wijaya (2012), Schumacker \& Lomax (2004), as listed in Table 4: Goodness of Fit, the level of compatibility of the research model relatively fulfills all the criteria, and belongs to the good category. This implies that the model used in this study is considered good and meets the existing standard reference criteria, by that general application can be done for other restaurants.

The results of interviews with food bloggers/food influencers were also conducted 
in this study to add information and provide qualitative support regarding the visualization of food display, food quality and the level of customer satisfaction at Tutup Panci Bistro. Results of interviews with the food reviewer indicate that the visualization of food displays contains stimulus to evocative sensory customers. With a good and attractive display of food, sensory customers send positive signals so that the customer's mood becomes positive, and relatively directly associates with good quality of food as well. The existence of such settings will boost the level of customer satisfaction. The role of the food display is crucial in an effort to create an unforgettable experience. In addition, stimulation for each of the five senses of a good customer will have a positive impact on all customer experiences, then there will be an increase in customer satisfaction (Ellen, Anantadjaya, \& Saroso 2014).

\section{CONCLUSSION}

Based on the results in this study, the conclusions that can be drawn are as follows; Visualization the food display has a large and significant impact on customer satisfaction at the restaurant Tutup Panci Bistro, amounting to $90 \%$. This research shows that the visualization of the food display in the Tutup Panci Bistro has an added value offered to its customers and visitors. The quality of food has a strong positive impact on customer satisfaction at the Tutup Panci Bistro restaurant, amounting 55\%. When a restaurant has a good quality products, accompanied by good service that is well supported by the appropriate price, access to easy location, and good promotion, then the combination of it will attract customers to make a return visit to the Tutup Panci Bistro restaurant.

The results of this study are statistically proven that there is a relationship between the food display and food quality to customer satisfaction at the restaurant Tutup Panci Bistro restaurant. Referring to the results of the research, the recommendations that can be formulated are as follows; Certainly by working with the chef, the results of this research can be considered to be applied in other restaurants to achieve a balance between the food display with the quality of its food. Food stylist is required that can ensure the visualization of the display of food served, absolutely by paying attention to components, colors, textures, shapes \& sizes, layout, service quality (Soenawan \& Malonda 2015, Exhibitions, Moizers, \& Pettinicchio 2010, Ghimire 2012, Ha \& Jang 2010), appropriate prices (Soenawan \& Malonda 2015, Faizah, Suryoko, \& Saryadi 2013), and the restaurant's physical/atmospheric environment (Ha \& Jang, 2010, Githiri 2017) is good.

The results of the study are useful for the management of Tutup Panci Bistro to continue developing new innovations with the creation other added values. The variables and sub-variables used in this study are still relatively limited. Further research needs to consider other variables, including a longer time span, then it can involve more customers, including new visitors who came because it held a specific event.

\section{ACKNOWLEDGMENTS}

Feel free to impress your gratitude to person(s) that help you in accomplish the research. Please keep the paragraph not more than 200 words.

\section{REFERENCES}

Adam, M. A., \& Ali, K. (2014). Impact of Visual Packaging Elements of Packaged Milk on Consumer Buying Behavior. Interdisciplinary Journal of Contemporary Research in Business, 5(11).

Al-Tit, A. A. (2015). The Effect of Service and Food Quality on Customer Satisfaction and Hence Customer Retention. Asian Social Science, 11(23), 129-139. 
doi:10.5539/ass.v11n23p129

Anantadjaya, S. P., \& Nawangwulan, I. M. (2018). Simple Step for Your Business Research: Tips \& Tricks. In Satiri, T. A. Rachmat, \& B. W. Saputra (Ed.). BSD City, Banten, Indonesia: PT. Kang Guru Beruang. Retrieved from kangguruberuang.blogspot.co.id

Anantadjaya, S. P., Nawangwulan, I. M., Kusumah, A. I., Setio, Y., \& Kartika, C. (2015). Does the Image of Indonesian Contemporary Artists Matter? A Theoretical Review on Personal Diversity, Brand Image, Market Acceptance \& Market Opportunity. Independent Journal of Management \& Productivity, 6(2), 378-422. doi:10.14807/ijmp.v6i2.280

Arbuckle, J. L. (2011). IBM SPSS Amos 20 User's Guide. New York: IBM Corporation.

Bennet, T. (2017). Marketing Strategies: How Small Restaurant Business use Social Media. Dissertation - Walden University Scholar Works. In P. Fusch, R. Snyder, T. Malone, \& E. Riedel (Ed.). Minnesota, MN, USA: Walden University. Retrieved from https://scholarworks.waldenu.edu/cgi/viewcontent.cgi?article=4532\&context=dissertatio ns

Bojanic, $\bar{D}$. C. (2007). Global Pricing Strategy for a Quick-Service Restaurant Chain. Hospitality Review, 25(1), Article $4 . \quad$ Retrieved from http://digitalcommons.fiu.edu/hospitalityreview/vol25/iss1/4?utm source=digitalcommo ns.fiu.edu\%2Fhospitalityreview\%2Fvol25\%2Fiss 1\%2F4\&utm medium=PDF\&utm cam paign=PDFCoverPages

Cameran, M., Moizer, P., \& Pettinicchio, A. (2010). Customer Satisfaction, Corporate Image, and Service Quality in Professional Services. Service Industries Journal, 30(3), 421435. doi:10.1080/02642060802236111

Caribbean Hotel Association. (2003). Food Presentation General Guidelines. Retrieved from http://www.caribbeanhotelandtourism.com/cshae/docs/food-presentation-manual.pdf

Chef Resources Inc. (2015). The Art of Plate Presentation. Retrieved from https://www.chefsresources.com/?s=skeleton+of+plate

Civille, G. V. (2010). Food Texture: Pleasure and Pain. Journal of Agricultural Food Chemistry, 59(5), 1487-1490. doi: https://doi.org/10.1021/jf100219h

Collinge, R. (2017). The Importance of Visual Appeal in Web Design. (usabilla.com) Retrieved from https://usabilla.com/blog/visual-appeal-web-design/

Cooper, D. R., \& Schlinder, P. S. (2011). Business Research Method (11th ed.). Singapore: McGraw-Hill Education (Asia).

Darmayana, H. (2017). Semakin Banyak Orang Indonesia Alami Obesitas. CNN Indonesia, p. Gaya Hidup/Berita Kesehatan. Retrieved from https://www.cnnindonesia.com/gayahidup/20170302223030-255-197500/semakin-banyak-orang-indonesia-alami-obesitas

Dhetira, A. (2016). Gastrofest 2016 Siap Majukan Industri Kuliner Indonesia. SWA, pp. TrendsManagement. Retrieved from https://swa.co.id/swa/trends/management/gastrofest2016-siap-majukan-industri-kuliner-indonesia

Ellen, C., Anantadjaya, S. P., \& Saroso, P. A. (2014). Determinants of Entrepreneurial Success on Indonesian Food Service MSMEs. RIBER: Review of Integrative Business \& Economics Research, 3(1), 81-98. Retrieved from http://sibresearch.org/uploads/3/4/0/9/34097180/riber k14-028 81-98.pdf

Elliot, A. J., \& Maier, M. A. (2014). Color Psychology: Effects of Perceiving Color on Psychological Functioning in Humans. Annual Review of Psychology, 65, 95-120.

Faizah, N. R., Suryoko, S., \& Saryadi. (2013). Pengaruh Harga, Kualitas Produk dan Kualitas Pelayanan Terhadap Kepuasan Pelanggan Restoran O-Mamamia Steak dan Ice Cream Cabang Jati Semarang. Diponegoro Journal of Social and Politics, 1-8. Retrieved from http://ejournal-s1.undip.ac.id/index.php/

Fernando, P. (2018). Food Reviewer \& Blogger. BSD City, Serpong, Tangerang, Banten, Indonesia: PT. Tutup Panci Indonesia.

Field, A. (2005). Factor Analysis Using SPSS. Retrieved from www.statisticalshell.com

Fu'ad, E. N. (2015). Pengaruh Pemilihan Lokasi Terhadap Kesuksesan Usaha Berskala Mikro/Kecil di Komplek Shopping Centre Jepara. Media Ekonomi dan Manajemen, 30(1), 56-67. 
Ghauri, P., \& Gronhaug, K. (2005). Research Methods in Business Studies: A Practical Guide (3rd ed.). London, UK: Prentice Hall.

Ghimire, A. J. (2012). Service Quality and Customer Satisfaction in the Restaurant Business: Case Study-Sagarmatha Nepalese Restaurant in Vantaa. Retrieved from https://www.theseus.fi/handle/10024/46914

Ghozali, I. (2004). Model Persamaan Struktural: Konsep dan Aplikasi dengan Program AMOS ves. 5.0. Semarang, Jawa Tengah, Indonesia: Badan Penerbit Universitas Diponegoro.

Ghozali, I. (2009). Aplikasi Analisis Multivariate Dengan Program SPSS (4th ed.). Semarang, Jawa Tengah, Indonesia: Badan Penerbit Universitas Diponegoro.

Githiri, M. N. (2017). Influence of Physical Environment on Customer Satisfaction and Return Intention in Kenyan Rated Restaurants. Asian Journal of Social Science Studies, 2(1), 11-19. doi: 10.20849/ajsss.v2i1.82

Gitman, L. J., \& McDaniel, C. D. (2007). The Future of Business (6th ed.). Mason, Ohio, USA: Cengage Learning.

Goeldner, C. R., \& Ritchie, J. B. (2009). Tourism: Principles, Practices, Philosophies (11th ed.). Hoboken, New Jersey, USA: John Wiley \& Sons, Inc.

Gustafsson, A., Johnson, M. D., \& Roos, I. (2005). The Effects of Customer Satisfaction, Relationship Commitment Dimensions, and Triggers on Customer Retention. Journal of Marketing, 69(4), 210-218. doi: https://psycnet.apa.org/doi/10.1509/jmkg.2005.69.4.210

Ha, J., \& Jang, S. S. (2010). Effects of Service Quality and Food Quality: The Moderating Role of Atmospherics in an Ethnic Restaurant Segment. International Journal of Hospitality Management, 29(3), 520-529. doi: http://dx.doi.org/10.1016/j.jjhm.2009.12.005

Han, H., \& Ryu, K. (2009). The Roles of the Physical Environment, Price Perception, and Customer Satisfaction in Determining Customer Loyalty in the Restaurant Industry. Journal of Hospitality \& Tourism Research, 33(4), 487-510. doi: $10.1177 / 1096348009344212$

Hanover College. (n.d.). Reliability Analysis. Retrieved from https://psych.hanover.edu/classes/ResearchMethods/Assignments/reliability-1.html

Hauff, A. (2019). The Know It All Guide to Color Psychology in Marketing + The Best Hex Chart. Retrieved from https://coschedule.com/blog/color-psychology-marketing/

Haugaard, P. (2015). Meal Satisfaction: Focusing on Meals in Worksite Environment. Dissertation, School of Business and Social Sciences. In L. Lähteenmäki, L. Esbjerg, M. Raats, F. A. Perez-Cueto, \& J. Aschemann-Witzel (Ed.). Aarhus, Denmark: Aarhus University. Retrieved from https://badm.au.dk/fileadmin/Business Administration/PhD/PhD thesis P.Haugaard.pd $\underline{f}$

Hsu, L., \& Wu, P. (2013). Electronic-Tablet-Based Menu in a Full Service Restaurant and Customer Satisfaction-A Structural Equation Model. International Journal of Business, Humanities and Technology, 3(2), 61-71. Retrieved from http://www.ijbhtnet.com/journals/Vol 3 No 2 February 2013/6.pdf

IBM SPSS Amos. (2018b). Validity \& Reliability Tests. SPSS Output. In S. P. Anantadjaya, (Compiler). BSD City, Serpong, Banten, Indonesia: IBM SPSS Amos.

IBM SPSS Amos. (2018c). Regression Weight. Amos Output. In A. N. Putra, S. P. Anantadjaya, \& I. M. Nawangwulan (Compilers). BSD City, Serpong, Banten, Indonesia: IBM SPSS Amos.

Indra, J., \& Anantadjaya, S. P. (2011). Balancing the Firm's Scores: A Performance and Control Study in Indonesian Financing Industry. The 7th Asia Pacific Management Accounting Association (APMAA) Conference \& Doctoral Colloquium. Shah Alam, Selangor, Malaysia: APMAA \& UiTM.

Jeltema, M., Beckley, J., \& Vahalik, J. (2015). Model for Understanding Consumer Textural Food Choice. Food Science \& Nutrition, 3(3), 202-212. doi: 10.1002/fsn3.205

Kotler, P., \& Armstrong, G. (2014). Principles of Marketing (15th ed.). Essex, UK: Pearson Education Limited.

Labensky, S. R., Hause, A. M., Labensky, S. R., \& Martel, P. A. (2014). On Cooking: A Textbook of Culinary Fundamentals (5th ed.). Essex, UK: Pearson Education Limited. 
McCurry, J. (2018). Looks Good Enough to Eat: Inside the Home of Japan's Fake Food Industry. Retrieved from theguardian.com/world $/ 2018 / \mathrm{mar} / 03 /$ looks-good-enought-toeat-inside-the-home-of-japans-fake-food-industry

Motes, M. A., Malach, R., \& Kozhevnikov, M. (2008). Object-Processing Neural Efficiency Differentiates Object from Spatial Visualizers. Neuro Report, 19(17), 1727-1731. doi: 10.1097/WNR.0b013e328317f3e2.

Munada, N. S. (2017). Dinamika Kepribadian Tangguh Pada Mahasiswa Obesitas yang Berhasil Menurunkan Berat Badan: Komitmen, Kontrol, dan Tantangan Sebagai Kunci Keberhasilan. Retrieved from http://etd.repository.ugm.ac.id

Mustafa, Z., \& Wijaya, T. (2012). Panduan Teknik Statistik SEM \& PLS dengan SPSS AMOS. Yogyakarta: Cahaya Atma Pustaka.

Mwangi, A. (2010). The Art and Science of Food Garniture. Retrieved from https://www.theseus.fi/handle/10024/33511

Nawangwulan, I. M., Anantadjaya, S. P., Widayatmoko, D., \& Hulu, D. (2012). Building Conditions and Facilities Improve Customer Satisfaction? An Evidence of Consumer Behaviors in Office Buildings. Society of Interdisciplinary Business Research, 1(1), 2012-047.

Nisbets PLC. (2019). The Art of Food Plating. (Nisbets PLC, UK) Retrieved from https://www.nisbets.co.uk/the-art-of-food-plating

Okumu, J. (2012). Importance of Customer Satisfaction in Waskia Restaurant. In H. Alamäki (ed.). Retrieved from http://citeseerx.ist.psu.edu/viewdoc/download?doi=10.1.1.843.8746\&rep=rep1\&type=p $\underline{\mathrm{df}}$

Oliver, R. L. (1999). Whence Consumer Loyalty?. Journal of Marketing, 63(Special), 33-44. Retrieved from http://citeseerx.ist.psu.edu/viewdoc/download?doi=10.1.1.454.2827\&rep=rep1\&type=p $\underline{\mathrm{df}}$

Pardede, T. E., Rosdiana, D., \& Christianto, E. (2017). Gambaran Pengendalian Diabetes Melitus Berdasarkan Parameter Indeks Massa Tubuh dan Tekanan Darah di Poli Rawat Jalan Penyakit Dalam RSUD Arifin Achmad Pekan baru. Jurnal Online Mahasiswa Fakultas Kedokteran, 1(4), 1-4.

Pearson Education. (2018). PHStat 4. Add-Ins Program to Excel 2016. USA: Pearson Education.

Pulos, E., \& Leng, K. (2010). Evaluation of a Voluntary Menu-Labelling Program in Full-Service Restaurants. American Journal of Public Health, 100(6), 1035-1039. doi: https://dx.doi.org/10.2105\%2FAJPH.2009.174839

Putra, A. N. (2019). Tampilan Makanan \& Kualitas Makanan = Kepuasan Pelanggan?. In S. P. Anantadjaya, \& I. M. Nawangwula (ed.). Beau Bassin, Mauritius: Globe Edit, International Book Market Service, Ltd., member of Omni Scriptum Publishing Group, Germany.

Putra, A. N., Saroso, P. A., \& Anantadjaya, S. P. (2015). Physical Menu Design: One Important Marketing Tool. In I. M. Nawangwulan (ed.). Saarbrucken, Germany: LAP Lambert Academic Publishing.

Raosoft. Inc. (2004). Sample Size Calculator. Retrieved from http://www.raosoft.com/samplesize.html

Ray, A. (2015). Food Plating: The Art of Food Presentation. The Art Institutes. Retrieved from https://www.artinstitutes.edu/about/blog/food-plating-the-art-of-food-presentation

Reid, R. D., \& Bojanic, D. C. (2009). Hospitality Marketing Management. New Jersey, USA: John Wiley and Sons.

Rozekhi, N. A., Hussin, S., Siddiqe, A. S., Rashid, P. D., \& Salmi, N. S. (2016). The Influence of Food Quality on Customer Satisfaction in Fine Dining Restaurant: Case in Penang. International Academic Research Journal of Business and Technology, 2(2), 45-50. Retrieved from http://www.iarjournal.com/wp-content/uploads/IARJBT2016 2 45$\underline{50 . p d f}$ 
Sahari, N., Basir, N. M., \& Jangga, R. (2012). Factors of Food Dimension Affecting Customer Satisfaction in Family Restaurants. 3rd International Conference on Business and Economic Research, 2831-2846. Bandung. Retrieved from researchgate.net/publication/268407891 factors of food dimension affecting custom er satisfaction in family restaurants

Santoso, S. (2009). SEM, Konsep dan Aplikasinya pada AMOS. Jakarta, Indonesia: PT Elex Media Komputindo.

Sarwono, J. (2012). Metode Riset Skripsi Pendekatan Kuantitatif Menggunakan Prosedur SPSS. Jakarta: PT Elex Media Komputindo.

Schumacker, R. E., \& Lomax, R. G. (2004). A Beginner's guide to Structural Equation Modeling (2nd ed.). Upper Saddle River, NJ, USA: Lawrence Erlbaum Associates, Inc.

Sekaran, U., \& Bougie, R. (2009). Research Methods for Business (5th ed.). United Kingdom.

Shock, P. J., Bowen, J. T., \& Stefanelli, J. M. (2004). Restaurant Marketing for Owners and Managers. Hoboken, NJ, USA: John Wiley \& Sons, Inc.

Singh, N., \& Srivastava, S. K. (2011). Impact of Colors on the Psychology of Marketing - A Comprehensive Over View. Management and Labour Studies, 36(2), 199-209. doi: https://doi.org/10.1177\%2F0258042X1103600206

Soenawan, A. D., \& Malonda, E. S. (2015). Pengaruh Kualitas Produk, Kualitas Pelayanan dan Harga Terhadap Keputusan Pembelian Konsumen D'Stupid Baker Spazio Graha Family Surabaya. Undergraduate Thesis Review, 395-409. Retrieved from https://media.neliti.com/media/publications/84533-ID-pengaruh-kualitas-produkkualitas-pelaya.pdf

Spence, C., Okajima, K., Cheok, A. D., Petit, O., \& Michel, C. (2016). Eating with Our Eyes: From Visual Hunger to Digital Satiation. Brain and Cognition, 110, 53-63. doi: 10.1016/j.bandc.2015.08.006

Spence, C., Piqueras-Fiszman, B., Michel, C., \& Deroy, O. (2014). Plating Manifesto (II): The Art and Science of Plating. Flavor Journal, 3(4), 1-12. doi: https://doi.org/10.1186/20447248-3-4

Stewart, P. C., \& Goss, E. (2013). Plate Shape and Color Interact to Influence Taste and Quality Judgments. Flavour, 2(27), 1-9. doi: https://doi.org/10.1186/2044-7248-2-27

Sugiyono. (2017). Metode Penelitian Kuantitatif, Kualitatif dan $R \& D$. Bandung, Jawa Barat, Indonesia: Alfabeta.

The Manila Times. (2014). The Possibilities of Plating. The Manila Times. Retrieved from https://www.manilatimes.net/the-possibilities-of-plating/75842/

Thomas Jr, L., \& Mills, J. (2006). Consumer Knowledge and Expectations of Restaurant Menus and Their Governing Legislation: A Qualitative Assessment. Journal of Food Service, 17(1), 6-22. doi: http://dx.doi.org/10.1111/j.1745-4506.2006.00015.x

Tjiptono, F. (2014). Pemasaran Jasa: Prinsip, Penerapan dan Penelitian. Jogyakarta, DI Jogyakarta, Indonesia: Andi Publisher.

Unilever Food Solutions. (2016). The Basic of Food Plating. Retrieved from https://www.unileverfoodsolutions.co.nz/chef-inspiration/cheflife/the-basics-of-foodplating.html

Velasco, C., Michel, C., Woods, A. T., \& Spence, C. (2016). On the Importance of Balance to Aesthetic Plating. International Journal of Gastronomy and Food Science, 5-6, 10-16. doi: https://doi.org/10.1016/j.ijgfs.2016.08.001

Vijayakurmaran, R. K., \& Amalina, S. N. (2018). Influences of Nutrition Information on Fast Food Consumption Among Undergraduates. Food Research, 2(3), 228-233. doi: https://doi.org/10.26656/fr.2017.2(3).288

Weaver, D., \& Lawton, L. (2014). Tourism Management (5th ed.). New York City, NY, USA: Wiley.

Wijaya. (2009). Analisis Structural Equation Modeling Menggunakan AMOS. Yogyakarta, Indonesia: Universitas Atmajaya.

Wirtz, J., \& Lovelock, C. H. (2016). Services Marketing: People, Technology, Strategy (8th ed.). Hackensack, NJ, US: World Scientific Publishing Co., Inc.

Yong, C. K., Siang, D. O., Lok, T. W., \& Kuan, W. Y. (2013). Factors Influencing Dining 
Experience on Customer Satisfaction and Revisit Intention Among Undergraduates Towards Fast Food Restaurants. Faculty of Accountancy and Management, Department of International Business. Kuala Lumpur: Universiti Tunku Abdul Rahman. Retrieved from http://eprints.utar.edu.my/1064/1/Factors Influencing Dining Experience on Custome $r$ Satisfaction and Revisit Intention among Undergraduates towards Fast Fo 1.pd $\underline{f}$ 